\title{
PENERAPAN MODEL PEMBELAJARAN WORD SQUARE PADA MATERI GLOBALISASI UNTUK MENINGKATKAN HASIL BELAJAR SISWA KELAS IV SEMESTER II SDN SIDOREJO I KABUPATEN TUBAN TA 2016-2017 Iis Daniati Fatimah UNIROW Tuban e-mail: iisdaniatifatimah2@gmail.com
}

\begin{abstract}
Abstrak: Adapun tujuan dari Penelitian in i yaitu untuk mengetahui peningkatan hasil belajar siswa melalui pembelajaran word square pada materi globalisasi dengan subjek penelitian adalah siswa kelas IV SDN Sidorejo I kabupaten Tuban T.A 2016-2017 yang berjumlah 30 siswa. Para siswa tersebut terdiri dari 15 putra dan 15 putri. Dari segi akademik, para siswa mempunyai kemampuan akademik yang heterogen. Yang melatarbelakangi penelitian ini adalah kurang tuntasnya sis wa dalam belajar materi g lobalisasi yang disebabkan oleh beberapa factor, salah satunya karena guru minim pengetahuan tentang pembelajaran terkini yang inovatif,kreatif dan imajinatif. Setelah melakukan observasi, maka diperlukan adanya perbaikan pembelajaran yang dilaksanakan dalam dua siklus. Data prasiklus rata- rata kelas $68.7 \%$ dengan siswa yang mendapat nilai $\geq 75$ sebanyak 8 siswa dan yang mendapat nilai $\leq 75$ sebanyak 22 siswa. Siklus I di peroleh rata- rata kelas $74.3 \%$ dengan siswa yang mendapat nilai $\geq 75$ sebanyak 14 siswa dan yang mendapat nilai $\leq 75$ sebanyak 16 siswa. Karena belum mencapai KKM mata pelajaran PKn maka dilakukan tindakan pada siklus berikutnya yaitu siklus II, diperoleh rata- rata kelas $83.7 \%$ dengan siswa yang mendapat nilai $\geq 75$ sebanyak 24 siswa dan yang mendapat nilai $\leq 75$ sebanyak 6 siswa. Dari hasil yang diperoleh pada siklus II maka tidak diperlukan siklus berikutnya. Adapun peningkatan ketuntasan hasil belajar siswa kelas IV SDN Sidorejo I mata pelajaran PKn materi Globalisasi mulai dari tahap prasiklus, siklus I dan siklus II adalah dari nilai $68.7 \%$ menjadi 74.3 terjadi peningkatan sebesar 5.6\% dan dari $74.3 \%$ menjadi $83.7 \%$ terjadi peningkatan sebesar $9.4 \%$. Artinya hasil belajar siswa dengan pembelajaran word square pada materi globalisasi mengalami peningkatan yang bis a dilihat pada paparan data prasiklus, siklus I dan siklus II.
\end{abstract}

\section{Kata Kunci: Word Square, Pembelajaran Word Square, Hasil Belajar}

\begin{abstract}
The purpose of this study is to find out the increase in student learning outcomes through word square learning in globalization material with the research subjects are fourth grade students of SDN Sidorejo I Tuban T.A 20162017 district which numbered 30 students. The students consisted of 15 sons and 15 daughters. In terms of academics, students have heterogeneous academic abilities. The background of this study is the lack of completeness of students in learning globalization material caused by several factors, one of which is because teachers lack knowledge about the latest learning that is innovative, creative and imaginative. After making observations, it is necessary to improve learning carried out in two cycles. Prasiklus data averaged $68.7 \%$ with students who got a score of 875 as many as 8 students and who received a score of $\leq 75$ as many as 22 students. Cycle I was obtained $74.3 \%$ class average with students who got $\geq$ 75 as many as 14 students and who got $\leq 75$ as many as 16 students. Because it has not yet reached the KKM of Civics Subjects, the next cycle is carried out in the second cycle, which is $83.7 \%$ with students who get $\geq 75$ as many as 24 students and who get $\leq 75$ as many as 6 students. From the results obtained in cycle II, the next cycle is not needed. The increase in completeness of learning outcomes of fourth grade students of SDN Sidorejo I Civics subject matter Globalization starting from the pre-cycle stage, cycle I and cycle II are
\end{abstract}




\section{ELSE (Elementary School Education Jaurnal)}

Volume 3 Nomor 1 Februari 2019

P-ISSN: 2581-1800 E-ISSN: 2597-4122

Email: else@um-surabaya.ac.id

from $68.7 \%$ to 74.3 an increase of $5.6 \%$ and from $74.3 \%$ to $83.7 \%$ an increase of $9.4 \%$. This means that student learning outcomes with word square learning on globalization material has increased which can be seen in pre-cycle data exposure, cycle I and cycle II.

Keywords: Word S quare, Word S quare Learning, Learning Outcomes

\section{PENDAHULUAN}

Mengajar adalah aktivitas utama bagi seorang guru, maka bagi guru sekolah dasar diharapkan mampu menyampaikan materi dengan mudah dan lugas supaya siswa tidak mengalami kebimbangan dalam belajar. Salah satu pelajaran yang harus dijelaskan oleh guru adalah tentang pendidikan kewarganegaraan. Dimana pendidikan kewarganegaraan dapat di elaborasi pada bab I pasal 1 (2) UU nomor 12 tahun 2006 tentang kewarganegaraan Indonesia. Kewarganegaraan adalah hal ihwal yang berhubungan dengan warga Negara.

Dalam kewarganegaraan, tercipta ikatan antara individu dengan negara, dimana individu secara politis dan yuridis merupakan anggota penuh dari negara dan berkewajiban setia kepada negara: sebaliknya negara berkewajiban melindungi setiap warga negaranya. Sama halnya dengan materi globalisasi yang disampaikan kepada siswa, bahwa setiap individu dapat terhubung dan saling bertukar informasi dimanapun atau kapanpun melalui media elektronik dan cetak. Globalisasi dapat menjadikan suatu Negara lebih kecil karena kemudahan komunikasi antar Negara dalam berbagai bidang seperti pertukaran informasi dan perdagangan.

Terkait dengan penelitian ini, peneliti tertarik dengan permasalahan-permasalahan yang menyangkut tantangan globalisasi saat ini dengan abad 21 yang dirumuskan dalam judul penelitian. Untuk memudahkan siswa memahami materi maka peneliti menggunakan model pembelajaran word square. Menurut Mudjion (1999), word square adalah sejumlah kata yang disusun sehingga kata kata tersebut dapat dibaca ke depan dan ke belakang.

Maka dari itu, guru haruslah menyikapi keadaan seperti ini merefleksi pembelajaran yang telah dilakukan memperbaiki kekurangannya dan meningkatkan kelebihannya dalam mengajar supaya anak dapat tertarik dan dapat mengikuti pembelajaran dengan baik. Akan tetapi, masih banyak siswa yang memperoleh nilai di bawah KKM terutama pada materi globalisasi. Maka peneliti dianggap perlu memperkenalkan, memahami, mengembangkan 
dan menerapkan model pembelajaran word square guna untuk mengetahui peningkatan hasil belajar siswa kelas IV SDN Sidorejo I TA 2016-2017.

\section{METODE PENELITIAN}

Jenis penelitian ini adalah penelitian tindakan kelas (PTK), dimana dalam PTK terjadi kerjasama antara peneliti dengan (a) guru, (2) dua orang observer yang membantu dalam pengamatan untuk mengambil data selama penelitian. Desain penelitian yang digunakan mengacu pada model Kemmis dan M.C Taggart dalam Susilo (2008) yang terdiri empat komponen, yaitu: perencanaan tindakan, pelaksanaan tindakan, observasi dan refleksi.

Penelitian tindakan kelas dalam penelitian ini dilakukan dengan dua siklus. Tiap siklus dilaksanakan perbaikan- perbaikan yang ingin dicapai melalui tahap refleksi. Selanjutnya memperoleh informasi tentang kondisi pembelajaran dan kondisi awal di kelas sebelum dilakukan tindakan. Pnelitian dilaksanakan pada Bulan Februari 2016 mata pelajaran PKn prasiklus, Bulan Maret 2016 siklus pertama dan Bulan April 2016 siklus kedua.

\section{Observasi Aktivitas Siswa}

Lembar observasi aktivitas siswa ini dibuat untuk memperoleh gambaran tentang aktivitas siswa selama proses pembelajaran berlangsung. Aktivitas siswa dalam mengikuti proses pembelajaran diskor berdasarkan aktivitas-aktivitas siswa di dalam kelas. Aktivitasaktivitas siswa pada proses pembelajaran yang diamati adalah aktivitas siswa pada saat bertanya, mengeluarkan pendapat, bekerja dalam kelompok dan diskusi. Data hasil observasi aktivitas siswa dianalisis dengan menggunakan persentase sebagai berikut.

Persentase nilai rata-rata $(N R)=\frac{\text { jumlah skor }}{\text { skor maksimal }} \times 100 \%$

Taraf keberhasilannya sebagai berikut.

$\begin{array}{ll}90 \% \leq N R \leq 100 \% & : \text { sangat baik } \\ 80 \% \leq N R<90 \% & \text { : baik } \\ 70 \% \leq N R<80 \% & : \text { cukup } \\ 60 \% \leq N R<70 \% & : \text { kurang } \\ 0 \% \leq N R<60 \% & \text { : sangat kurang }\end{array}$


Aktivitas siswa dikatakan baik jika rata-rata skor dari semua aspek yang dinilai berada pada kategori baik atau sangat baik. Dengan demikian, maka hasil analisis data yang tidak memenuhi dari salah satu kategori baik atau sangat baik pada penelitian ini akan dijadikan bahan pertimbangan untuk merevisi perangkat pembelajaran yang telah diujicobakan.

Data hasil belajar siswa diambil dengan memberikan tes pada setiap akhir siklus. Data hasil belajar dianalisis dengan menggunakan ketuntasan individual dan ketuntasan klasikal terhadap indikator yang telah ditetapkan. Ketuntasan individual atau ketuntasan per siswa ditentukan dengan rumus:

$$
\begin{array}{ll}
\mathrm{K}={ }^{\frac{T}{T t}} \times & 100 \% \\
\mathrm{~K} & =\begin{array}{l}
\text { Persentase ketuntasan belajar siswa per siswa } \\
\quad \text { (proporsi jawaban yang benar) }
\end{array} \\
\mathrm{T} & =\text { Jumlah indikator yang tuntas per siswa } \\
\mathrm{Tt} & =\text { Jumlah indikator keseluruhan }
\end{array}
$$

\begin{tabular}{|c|c|c|c|c|}
\hline \multirow{2}{*}{ No. } & \multirow{2}{*}{ Nama Sis wa } & \multirow{2}{*}{ Tes Awal } & \multicolumn{2}{|c|}{ Ketuntasan Hasil Belajar } \\
\hline & & & Ya & Tidak \\
\hline 1 & Andre Aldiansyah & 60 & & $\sqrt{ }$ \\
\hline 2 & Dira Aulia & 70 & & $\sqrt{ }$ \\
\hline 3 & Dimas Firdian & 80 & $\sqrt{ }$ & \\
\hline 4 & Siti Nuris Syafaah & 70 & & $\sqrt{ }$ \\
\hline 5 & Anton Hidayat & 70 & & $\sqrt{ }$ \\
\hline 6 & Elmiatun & 50 & & $\sqrt{ }$ \\
\hline 7 & Faidatul Hasanah & 40 & & $\sqrt{ }$ \\
\hline 8 & Faridatul Hasanah & 70 & & $\sqrt{ }$ \\
\hline 9 & Fatimah Wardatul & 70 & & $\sqrt{ }$ \\
\hline 10 & Muhammad Fadilla & 60 & & $\sqrt{ }$ \\
\hline 11 & Natifatul Hasanah & 80 & $\sqrt{ }$ & \\
\hline 12 & Saifur Ridho & 70 & & $\sqrt{ }$ \\
\hline 13 & Siti Asiyah & 70 & & $\sqrt{ }$ \\
\hline 14 & Sumiati & 90 & $\sqrt{ }$ & \\
\hline 15 & Alfis Malik & 80 & $\sqrt{ }$ & \\
\hline 16 & Ahmad Sohib & 70 & & $\sqrt{ }$ \\
\hline 17 & Alfian Ramadhani & 90 & $\sqrt{ }$ & \\
\hline 18 & Dini lailatus s. & 70 & & $\sqrt{ }$ \\
\hline 19 & Faiqatul Muawanah & 60 & & $\sqrt{ }$ \\
\hline 20 & Laa Raiba Fiih & 70 & & $\sqrt{ }$ \\
\hline 21 & Liatul Faisah & 60 & & $\sqrt{ }$ \\
\hline 22 & Mufrida Faradiani & 80 & $\sqrt{ }$ & \\
\hline 23 & Mohammad Aqil & 70 & & $\sqrt{ }$ \\
\hline 24 & M. Ardiansyah & 70 & & $\sqrt{ }$ \\
\hline
\end{tabular}

\section{HASIL DAN PEMBAHASAN}

\section{Hasil Tes Awal Ketuntasan Hasil Belajar Sis wa Kelas IV SD Sidore jo I}


Volume 3 Nomor 1 Februari 2019

P-ISSN: 2581-1800 E-ISSN: 2597-4122

Email: else@um-surabaya.ac.id

\begin{tabular}{llrrr}
\hline \multirow{2}{*}{ No. } & Nama Siswa & Tes Awal & \multicolumn{2}{c}{ Ketuntasan Hasil Belajar } \\
\hline 25 & Muhammad Imam & 50 & $\sqrt{ }$ & Yidak \\
26 & Muhammad Mukhlis & 80 & & $\sqrt{ }$ \\
27 & M. Rocky Apriliansyah & 60 & & $\sqrt{ }$ \\
28 & Muhammad Ubaidillah & 50 & $\sqrt{ }$ \\
29 & Restianingsih & 80 & & $\sqrt{ }$ \\
30 & Widiyanti & 70 & & \\
\hline \multicolumn{7}{c}{ Jumlah } & 2060 & & \\
\hline
\end{tabular}

Tabel di atas menggambarkan bahwa hanya $24 \%$ siswa yang mendapat nilai $\geq 75$ dan $76 \%$ siswa lainnya memperoleh nilai $\leq 75$. Sedangkan KKM pembelajaran IPS dikatakan tuntas apabila $75 \%$ siswa tuntas belajar atau 24 siswa mendapat nilai $\geq 75$. Dengan hasil tes di atas, maka diperlukan tindakan guna memperbaiki pembelajaran.

Tabel 2. Klasifikasi Ketuntasan Hasil Belajar Sis wa Kelas IV SD Sidore jo I

\begin{tabular}{|c|c|c|c|}
\hline \multirow{2}{*}{ Nama Siswa } & \multirow{2}{*}{ Tes Siklus 2} & \multicolumn{2}{|c|}{ Ketuntasan Hasil Belajar } \\
\hline & & $\mathbf{Y a}$ & Tidak \\
\hline Andre Aldiansyah & 70 & & $\sqrt{ }$ \\
\hline Dira Aulia & 80 & $\sqrt{ }$ & \\
\hline Dimas Firdian & 100 & $\sqrt{ }$ & \\
\hline Siti Nuris Syafaah & 80 & $\sqrt{ }$ & \\
\hline Anton Hidayat & 80 & $\sqrt{ }$ & \\
\hline Elmiatun & 70 & & $\sqrt{ }$ \\
\hline Faidatul Hasanah & 70 & & $\sqrt{ }$ \\
\hline Faridatul Hasanah & 80 & $\sqrt{ }$ & \\
\hline Fatimah Wardatul & 90 & $\sqrt{ }$ & \\
\hline Muhammad Fadilla & 80 & $\sqrt{ }$ & \\
\hline Natifatul Hasanah & 90 & $\sqrt{ }$ & \\
\hline Saifur Ridho & 80 & $\sqrt{ }$ & \\
\hline Siti Asiyah & 80 & $\sqrt{ }$ & \\
\hline Sumiati & 100 & $\sqrt{ }$ & \\
\hline Alfis Malik & 100 & $\sqrt{ }$ & \\
\hline Ahmad Sohib & 80 & $\sqrt{ }$ & \\
\hline Alfian Ramadhani & 100 & $\sqrt{ }$ & \\
\hline Dini lailatus s. & 80 & $\sqrt{ }$ & \\
\hline Faiqatul Muawanah & 80 & $\sqrt{ }$ & \\
\hline Laa Raiba Fiih & 80 & $\sqrt{ }$ & \\
\hline Liatul Faisah & 80 & $\sqrt{ }$ & \\
\hline Mufrida Faradiani & 100 & $\sqrt{ }$ & \\
\hline Mohammad Aqil & 90 & $\sqrt{ }$ & \\
\hline M. Ardiansyah & 80 & $\sqrt{ }$ & \\
\hline Muhammad Imam & 70 & & $\sqrt{ }$ \\
\hline Muhammad Mukhlis & 100 & $\sqrt{ }$ & \\
\hline M. Rocky Apriliansyah & 70 & & $\sqrt{ }$ \\
\hline Muhammad Ubaidillah & 60 & & $\sqrt{ }$ \\
\hline Restianingsih & 100 & $\sqrt{ }$ & \\
\hline Widiyanti & 90 & $\sqrt{ }$ & \\
\hline Jumlah & 2510 & & \\
\hline Rata- rata & 83.7 & & \\
\hline
\end{tabular}


Dari paparan data dan hasil tes terlihat bahwa ada 24 siswa atau sebesar 83,7\% siswa yang mencapai skor $\geq 75$.

\section{Tabel 3. Hasil Observasi Aktivitas Guru}

\begin{tabular}{|c|c|c|c|}
\hline No. & Aspek-aspek yang diamati & Pengamat I & Pengamat II \\
\hline \multirow[t]{3}{*}{1.} & Membuk a pelajaran & & \\
\hline & - Kesesuaian kegiatan apersepsi dengan materi ajar & 3 & 4 \\
\hline & - Menyampaikan penjelasan materı pembelajaran & 3 & 3 \\
\hline \multirow[t]{7}{*}{2.} & Kegiatan Inti Pembelajaran & & \\
\hline & $\begin{array}{l}\text { Gu ru mengkondisikan sis wa sesuai langkah } \\
\text { pembelajaran word square }\end{array}$ & 3 & 4 \\
\hline & - Guru menyiapkan beberapa lembar lks word square & 3 & 3 \\
\hline & - $\quad$ Gu ru membimbing sis wa dalam pembelajaran word & & \\
\hline & $\begin{array}{l}\text { square } \\
\text { Menguasai kelas }\end{array}$ & 4 & 4 \\
\hline & - Melaksanakan pembelajaran secara runtut sesuai & 4 & 4 \\
\hline & dengan RPP & 3 & 3 \\
\hline \multirow[t]{3}{*}{3.} & Pemanfaatan Media Pembelajaran & & \\
\hline & - Menggunakan alat peraga secara efektif dan efisien & 4 & 3 \\
\hline & - Melibatkan siswa dalam pemanfaatan alat peraga & 3 & 3 \\
\hline \multirow[t]{4}{*}{4.} & Penutup & & \\
\hline & - Membimbing siswa menyimpu lkan materi pembelajaran & 3 & 3 \\
\hline & - Melakukan refleksi pe mbelajaran dengan me libatkan siswa & 3 & 3 \\
\hline & $\Sigma \mathrm{SKOR}$ & & \\
\hline
\end{tabular}

Oleh karena itu, setelah dilaksanakan siklus II ini telah berhasil, sehingga tidak dibutuhkan kegiatan siklus berikutnya. Maka penelitian ini telah berhasil karena sudah mencapai indikator keberhasilan yang sudah ditentukan.

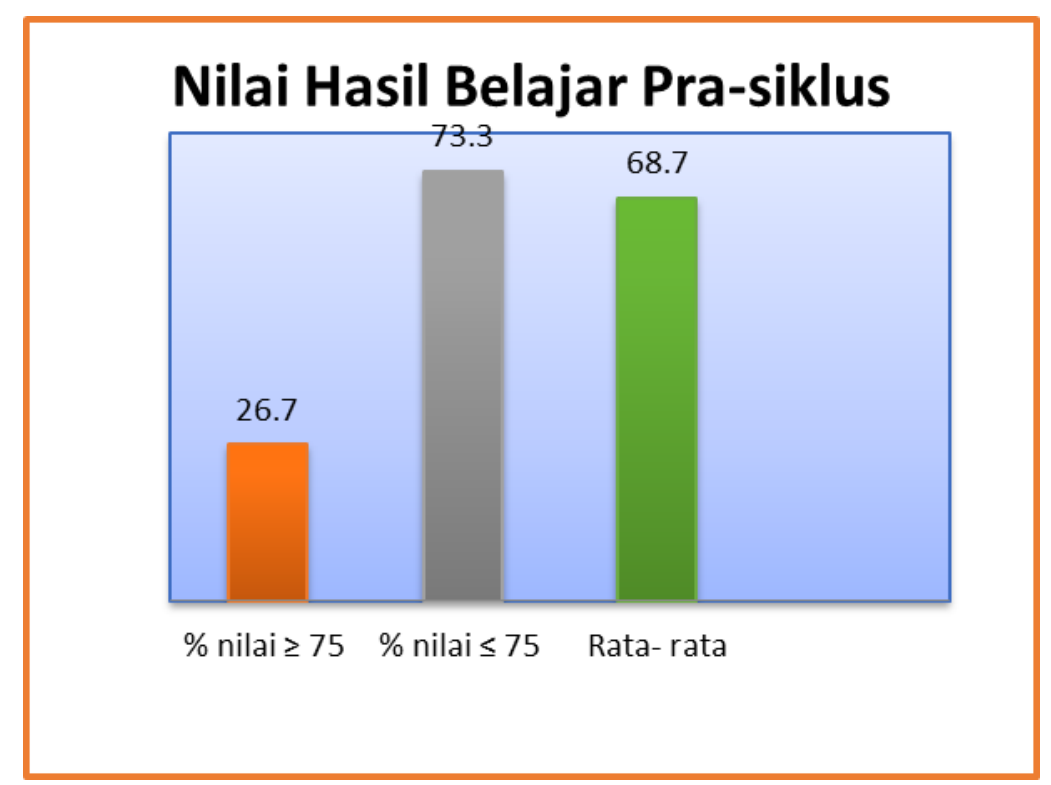

Gambar 1. Nilai Hasil Belajar Prasiklus 
Berdasarkan gambar di atas diketahui bahwa siswa yang memperoleh nilai $\geq 75$ yaitu $26 \%$ (8 siswa), yang memperoleh nilai $\leq 75$ adalah $74 \%$ (22 siswa) dengan nilai ratarata kelas yaitu 68.7. maka diperlukan suatu tindakan untuk memperbaiki nilai hasil belajar maka dari itu siklus I perlu dilaksanakan. Adapun gambar hasil belajar siklus I sebagai berikut.

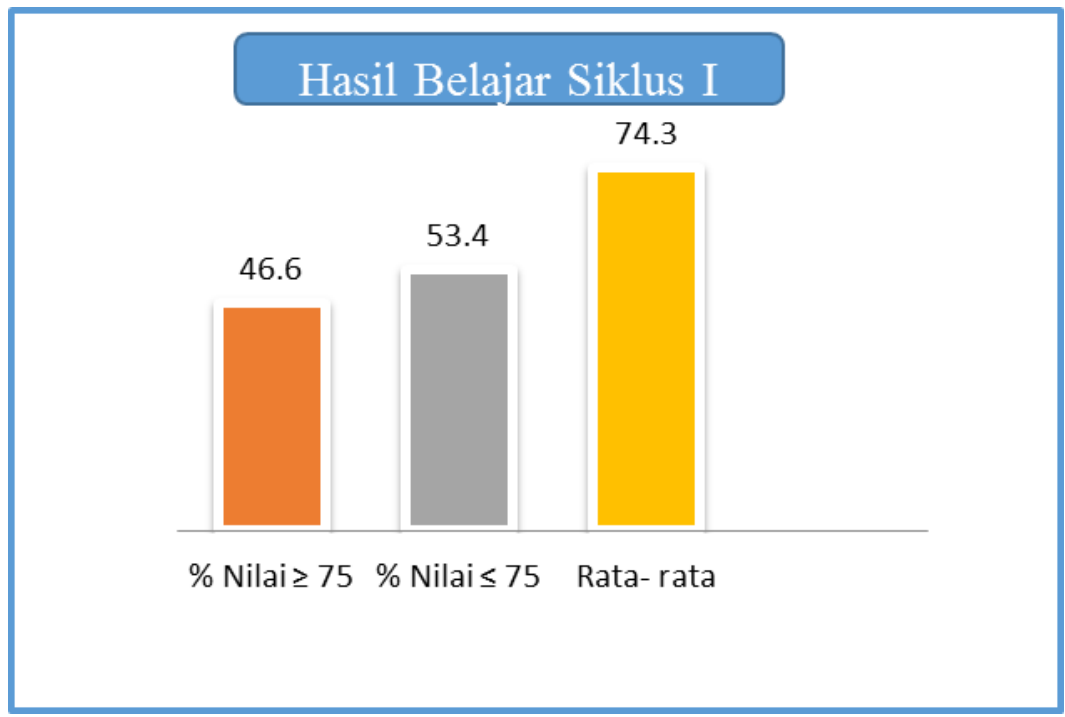

\section{Gambar 2. Nilai Hasil Belajar Siklus I}

Berdasarkan gambar di atas diketahui bahwa siswa yang memperoleh nilai $\geq 75$ yaitu $46.6 \%$ (14 siswa), yang memperoleh nilai $\leq 75$ adalah $53.4 \%$ (16 siswa) dengan nilai rata- rata kelas yaitu 74.3. Maka, diperlukan suatu tindakan untuk memperbaiki nilai hasil belajar supaya mencapai KKM mata pelajaran Pkn. Oleh karena itu, siklus II perlu dilaksanakan. Adapun gambar hasil belajar siklus II sebagai berikut. 


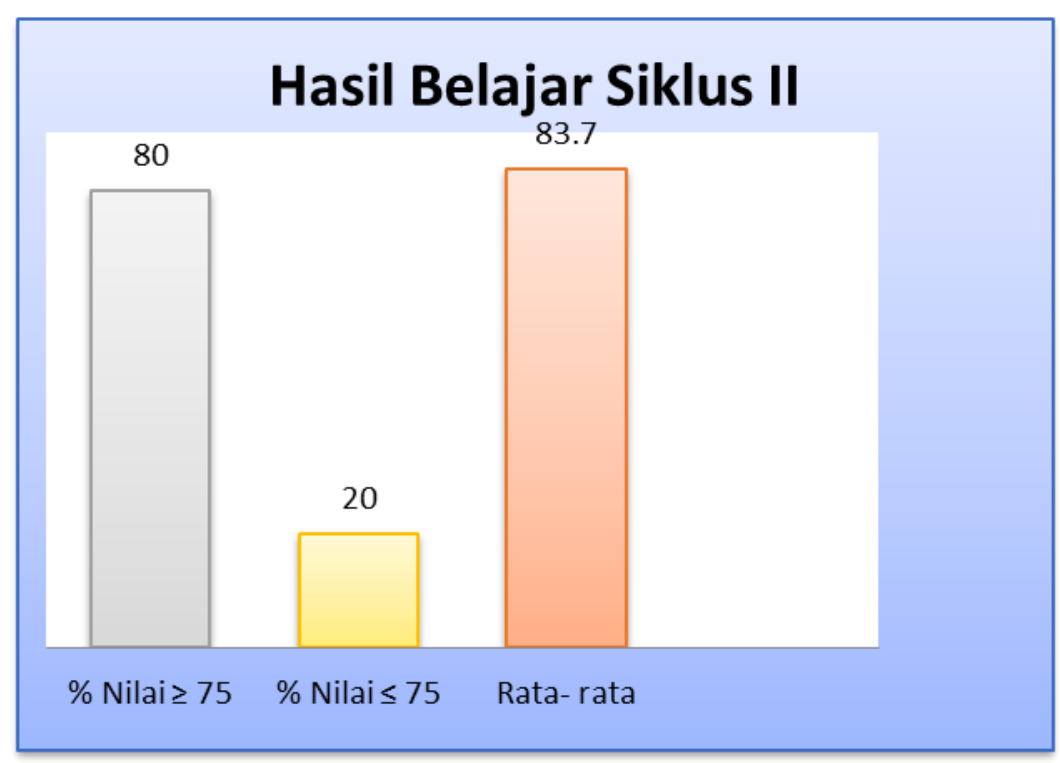

Gambar 3. Nilai Hasil Belajar Siklus II

Gambar di atas diketahui bahwa siswa yang memperoleh nilai $\geq 75$ yaitu $80 \%$ (24 siswa), yang memperoleh nilai $\leq 75$ adalah $6 \%$ (16 siswa) dengan nilai rata- rata kelas yaitu 83.7. Maka, dapat disimpulkan bahwa pada siklus II nilai hasil belajar siswa mencapai KKM mata pelajaran PKn. Oleh karena itu, tidak perlu dilakukan tindakan selanjutnya.

Berikut adalah gambar peningkatan ketuntasan hasil belajar siswa kelas IV SDN Sidorejo I Tuban mata pelajaran Pkn materi Globalisasi mulai dari tahap prasiklus, siklus I dan siklus II. 


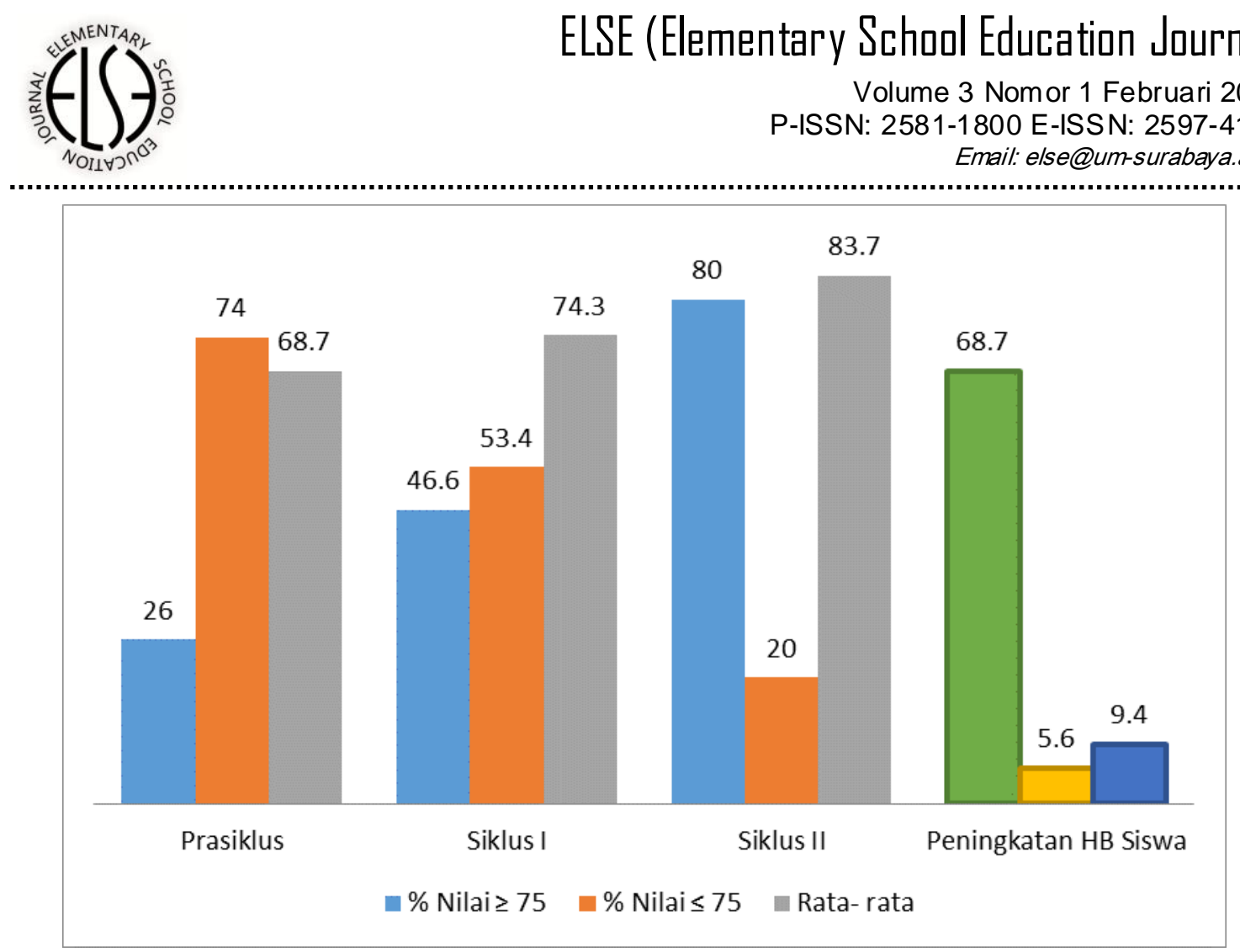

\section{Gambar 4. Peningkatan Ketuntasan Hasil Belajar Prasiklus, Siklus I dan Siklus II}

Dari gambar di atas dapat dijelaskan bahwa dari prasiklus rata- rata kelas $68.7 \%$ dengan siswa yang mendapat nilai $\geq 75$ sebanyak 8 siswa dan yang mendapat nilai $\leq 75$ sebanyak 22 siswa. Kemudian dilakukan siklus I dan di peroleh rata- rata kelas $74.3 \%$ dengan siswa yang mendapat nilai $\geq 75$ sebanyak 14 siswa dan yang mendapat nilai $\leq 75$ sebanyak 16 siswa. Karena belum mencapai KKM mata pelajaran PKn maka dilakukan tindakan pada siklus berikutnya yaitu siklus II, diperoleh rata- rata kelas $83.7 \%$ dengan siswa yang mendapat nilai $\geq 75$ sebanyak 24 siswa dan yang mendapat nilai $\leq 75$ sebanyak 6 siswa. Dari hasil yang diperoleh pada siklus II maka tidak diperlukan siklus berikutnya. Adapun peningkatan ketuntasan hasil belajar siswa kelas IV SDN Sidorejo I mata pelajaran PKn materi Globalisasi mulai dari tahap prasiklus, siklus I dan siklus II adalah dari nilai $68.7 \%$ menjadi 74.3 terjadi peningkatan sebesar $5.6 \%$ dan dari $74.3 \%$ menjadi $83.7 \%$ terjadi peningkatan sebesar $9.4 \%$.

\section{KESIMPULAN DAN SARAN}

Berdasarkan hasil penelitian yang dipaparkan pada Pembahasan maka dapat disimpulkan bahwa word square dapat membantu meningkatkan hasil belajar siswa pada kelas IV SDN Sidorejo I Tuban. Hal ini telah dibuktikan dengan adanya peningkatan ketuntasan hasil belajar siswa mulai dari tahap prasiklus, siklus I dan siklus II adalah dari 
nilai $68.7 \%$ menjadi 74.3 terjadi peningkatan sebesar $5.6 \%$ dan dari $74.3 \%$ menjadi $83.7 \%$ terjadi peningkatan sebesar $9.4 \%$.

Namun, pembelajaran word square pada materi globalisasi masih perlu membutuhkan persiapan karena para siswa belum mengal pembelajaran dengan model ini, oleh karena itu diperlukan manajemen waktu yang ideal dalam pelaksanaan pembelajaran dengan word square sehingga proses pembelajaran dapat berjalan efektif, efisien dan menyenangkan.

\section{DAFTAR PUSTAKA}

Ari Arikunto, Suharsimi, dkk. 2010. Penelitian Tindakan Kelas, Jakarta: Bumi Aksara.

Ari Kunto, Suharsimi. 1998. Dasar-dasar Evaluasi Pendidikan. Jakarta : Bumi Aksara.

Dimyati dan Mudjiono. 1999. Belajar dan Pembelajaran. Jakarta: Rineka Cipta.

Ibrahim, H. Muslimin. 2000. Pembelajaran Kooperatif. Surabaya: University Press.

Susilo, H. Chotimah, H \& Sari Y. D. 2008. Penelitian Tindakan Kelas Sebagai Sarana Pengembangan Keprofesionalan Guru dan Calon Guru. Malang: Bayumedia Publishing.

Sudjana, Nana. 1995. Penilaian Hasil Proses Belajar Mengajar. Bandung: PT. Remaja Rosda Karya. 